\title{
Stimulasi Denyut Jantung dengan Pemutar Musik pada Android
}

\author{
Ifan Kurnia Afandi ${ }^{\mathrm{a}^{*}}$, Ridi Ferdiana ${ }^{\mathrm{b}}$, Hanung Adi Nugroho ${ }^{\mathrm{c}}$ \\ abc Jurusan Teknik Elektro dan Teknologi Informasi, \\ Universitas Gadjah Mada, Yogyakarta
}

Naskah Diterima : 14 Oktober 2014; Diterima Publikasi : 12 Nopember 2014

\begin{abstract}
Music is a natural instrument that can be enter in every human life. Music used by the ancestors in traditional ceremonies and partly uses music to inspire the spirit of fighting on a war or on a sports competition. Music is also used by some people for relaxation. Music tempo affects heart rate in a unique way. Fast music tempo will increase the heart rate. Instead slow music tempo that tends to be used for relaxation. Today the daily activities can not be separated from smartphones and music. This paper presents a unique approach to increase the heart rate. Simple application become the base of application so that application can be use easily. Increased heart rate can be a support to maximize daily activities.
\end{abstract}

Keywords: Heart rate; Music; Smartphone

\begin{abstract}
Abstrak
Musik merupakan instrumen alam yang dapat masuk dalam setiap kehidupan manusia. Musik digunakan oleh nenek moyang dalam upacara adat dan sebagian menggunakan musik untuk mengobarkan semangat juang dalam perang atau dalam sebuah perlombaan olahraga. Musik juga digunakan oleh sebagian orang untuk relaksasi. Tempo musik mempengaruhi denyut jantung dengan cara yang unik. Tempo musik yang cepat akan meningkatkan denyut jantung. Sebaliknya tempo musik yang cenderung pelan digunakan untuk relaksasi. Dewasa ini aktivitas sehari-hari tidak dapat dipisahkan dari smartphone dan musik. Paper ini menyajikan pendekatan unik untuk meningkatkan denyut jantung. Aplikasi yang sederhana menjadi dasar pengembangan sehingga mudah untuk digunakan. Peningkatan denyut jantung dapat menjadi penunjang dalam memaksimalkan aktifitas sehari-hari.
\end{abstract}

Kata Kunci: Denyut jantung; Musik; Smartphone

\section{Pendahuluan}

Musik merupakan instrumen yang banyak digunakan di seluruh dunia untuk mengiringi berbagai macam aktifitas hidup. Contoh yang paling sering dijumpai adalah sebagai pengiring pesta dan upacara pemujaan. Sedangkan aktifitas merupakan kegiatan yang dilakukan dalam keseharian manusia. Aktifitas dalam era digital sekarang ini membuat manusia cenderung malas bergerak dari tempatnya. Kecenderungan ini mengkibatkan otak akan mengirim sinyal untuk memperlambat denyut jantung. Akibatnya timbul rasa kantuk dikarenakan konsumsi oksigen pada otak akan berkurang. Untuk mengurangi rasa kantuk beberapa orang mendengarkan musik.

Banyak penelitian yang membahas keterkaitan antara denyut jantung dan musik Banyak penelitian yang membahas keterkaitan antara denyut jantung dan musik (Raglio et al., 2012) (De Castro et al., 2013) tetapi kebanyakan riset sebelumnya lebih menitikberatkan penggunaan musik untuk media

*) Penulis korespondensi: ifan.afandi@gmail.com relaksasi. Paper ini mengajukan pendekatan baru dan unik untuk meningkatkan denyut jantung melalui aplikasi pemutar musik pada smartphone berbasis Android. .

Pada prinsipnya aplikasi ini mempunyai manfaat untuk mengetahui denyut jantung secara mobile. Pengembangan selanjutnya aplikasi ini dapat dimanfaatkan sebagai media untuk meningkatkan denyut jantung. Sehingga aplikasi dapat digunakan sebagai penunjang dalam melakukan aktifitas seharihari. Aplikasi yang mudah digunakan dan nyaman dengan pengguna menjadi dasar pembuatan aplikasi ini.

Aplikasi bekerja dengan mengukur denyut jantung melalui lensa kamera dengan lampu flash. Setelah didapatkan data denyut jantungnya maka data akan diolah pada aplikasi. Langkah selanjutnya aplikasi akan memilih tempo musik yang akan menjadi outputnya.

Aplikasi ini telah dikembangkan dalam bentuk prototype. Paper ini merupakan dokumentasi awal untuk penelitian meningkatkan denyut jantung dengan 
aplikasi mobile. Bagian II dari paper merupakan tinjauan pustaka dan hipotesis. Alat dan bahan yang digunakan serta langkah kerja dijelaskan pada bagian III. Bagian IV merupakan hasil uji aplikasi berupa tabel subyek dan penelitian lebih lanjut pada bagian V.

\section{Kerangka Teori}

\subsection{Pengukuran Denyut Jantung}

Manusia mempunyai rentang denyut jantung normal antara $60 \mathrm{bpm}-100 \mathrm{bpm}$. Berbeda untuk setiap individunya, misalnya olahragawan cenderung memiliki denyut jantung yang lebih sedikit pada fase relaksasi dibandingkan dengan orang biasa. Usia dan jenis kelamin juga mempengaruhi denyut jantung seseorang. Pada usia lanjut jantung cenderung berdenyut lebih cepat dari pada pada usia yang masih muda.

Prinsip dasar pengukuran denyut jantung adalah untuk mengukur jumlah denyut jantung setiap menit. Hasil pengukuran akan di notasikan dengan beat per minutes (bpm). Pengukuran denyut jantung dilakukan dengan berbagai macam cara. Cara pertama tentu saja dilakukan secara medis, pengukuran ini menggunakan alat electrocardiogram (ECG). Kesulitan utama penggunaan ECG adalah ketersediaan alat dan aplikasi yang dapat dikembangkan sangat terbatas.

Berikutnya adalah pengukuran denyut jantung dengan menggunakan alat sensor yang telah dijual bebas misalnya produk dari omron, shunto, ataupun Samsung. Cara lain yang dapat digunakan adalah dengan menggunakan lensa kamera smartphone yang telah menggunakan lampu flash. Cara diatas mempunyai keunggulan dan kelemahan pada sisi validitas dan biaya yang akan dikeluarkan untuk diterapkan. Pemakaian sensor yang dijual bebas tentu mempunyai kelemahan pada sisi biaya tetapi pada sisi validitas akan lebih tinggi daripada dengan pemakaian kamera, begitu juga sebaliknya.

Beberapa penelitian menggunakan wireless sensors network (WSN) untuk mengukur denyut jantung dan sebagai media pengiriman data mentah pada aplikasi pengolah data (Hii dan Chung, 2011) (Fraile et al., 2010) (Nasri et al., 2013). Cara tersebut mungkin efektif untuk diterapkan dalam sebuah area dengan konektivitas yang stabil dan selalu tersedia. Banyak penelitian menggunakan bluetooth (Al-Taee et al., 2011) (Watanabe et al., 2012) (Weibo Song et al., 2012) sebagai protokol pengiriman data mentah yang di dapat dari alat sensor pengukur denyut jantung. Pertimbangan ini diambil karena sebagian besar perangkat mobile telah menyertakan bluetooth sebagai kelengkapan dasar produknya. Tetapi perangkat bluetooth mempunyai kelemahan jika diterapkan untuk aplikasi bergerak pada ruang terbuka.

Beberapa peneliti (Issac dan Ajaynath, 2012) (Sung-Yuan Ko et al., 2012) (Diab et al., 2013) menggunakan mikrokontroler untuk memperoleh data mentah. Data mentah berupa sinyal denyut jantung akan dikirimkan pada pengolah data dengan menggunakan protokol bluetooth. Penelitian diatas sulit diterapkan dalam kehidupan sehari-hari dengan banyaknya sensor mikrokontroler yang dipasangkan di badan.

Penggunaan lensa kamera untuk pengukuran denyut jantung (Singh et al., 2012) (Lakens, 2013) membuka peluang baru dalam pengembangan aplikasi ECG pada smartphone. Kemampuan kamera dengan spesifikasi 5 Megapixel telah dapat menangkap gambar dengan kecepatan 20 frame per detik. Kemampuan tersebut memungkinkan untuk menganalisa interval cahaya yang masuk dengan membandingkan darah yang kaya akan oksigen dan sebaliknya. Masih diperlukan penelitian lebih lanjut apakah terjadi overlap atau tidak sehingga validitasnya dapat dipertangungjawabkan.

Ho et al., (2013) mengajukan penelitian tentang aplikasi pengukur denyut jantung yang terdapat pada Google Play Store. Dengan prinsip kerja pengambilan interval interpulse dengan kamera dan lampu flash yang diletakkan di ujung jari untuk mendapatkan data awal. Penelitian ini menyimpulkan aplikasi yang terdapat pada Google Play Store dapat di pertanggungjawabkan validitasnya dalam kerangka pengukuran jumlah denyut jantung. Tetapi diperlukan penelitian lebih lanjut untuk pengukuran pada usia yang lebih bervariasi.

Penelitian lebih lanjut yang dilakukan Gregoski dan kawan-kawan (Gregoski et al., 2012) adalah membandingkan aplikasi pengukur denyut jantung. Pertama adalah alat pengukur denyut jantung yang terdapat pada fasilitas kesehatan. Kedua adalah aplikasi pengukuran dengan menggunakan lensa kamera dan lampu flash. Ketiga adalah alat ukur denyut jantung yang dijual dipasaran. Hasil yang diperoleh menunjukkan bahwa penggunaan lensa kamera sebagai alat ukur denyut jantung dapat mengukur jumlah denyut jantung secara valid. Batasan uji yang hanya mengukur jumlah denyut jantung akan menjadikan aplikasi sederhana dan mudah dikembangkan.

\subsection{Tempo Musik}

Tempo merupakan ukuran kecepatan irama pada musik. Tempo musik dinotasikan dengan beat per minute (bpm). Tempo musik dibagi menjadi tiga yaitu tempo lambat, tempo sedang dan tempo cepat. Tempo lambat adalah musik dengan kecepatan antara $40 \mathrm{bpm}$ - 69 bpm. Tempo sedang adalah musik dengan kecepatan 70 bpm - 100 bpm. Tempo cepat adalah musik dengan kecepatan 100 bpm - 208 bpm.

Banyak penelitian yang menarik kesimpulan bahwa tempo musik dapat mempengaruhi denyut jantung. Santoso (2002) menyimpulkan bahwa musik dengan tempo lambat mempengaruhi penurunan jumlah denyut jantung pada subyek yang sedang 
beraktifitas. Zeydi et al., (2011) juga menarik kesimpulan yang hampir sama, bahwa tempo musik mempengaruhi aktivitas denyut jantung dan konsumsi oksigen pasca operasi. Perbedaan penelitian adalah pada subyek yang digunakan. Zeidy menggunakan subyek pasien pasca operasi bedah. Penelitian ini menitikberatkan pada pengaruh tempo musik untuk stabilisasi denyut jantung. Tetapi penelitian ini belum dapat menyimpulkan apakah tempo musik yang cepat akan berpengaruh pada kenaikan denyut jantung atau sebaliknya.

Dousty dan Daneshvar (2010) meneliti tentang pengaruh musik pada sinyal listrik yang dihasilkan oleh jantung. Seperti diketahui bahwa saat jantung berdenyut akan menghasilkan sinyal listrik yang berbeda baik saat relaksasi ataupun saat jantung memompa darah. Sinyal listrik inilah yang digunakan sebagai dasar pengukuran denyut jantung pada ECG yang terdapat pada fasilitas-fasilitas kesehatan. Penelitian ini menggunakan beberapa jenis musik dengan berbagai variasi tempo musik. Disimpulkan bahwa variasi tempo musik akan mempengaruhi sinyal listrik yang dihasilkan jantung.

Berdasarkan penelitian yang dilakukan McCraty et al., (2001) diambil kesimpulan bahwa aliran musik dan temponya berpengaruh pada variabel denyut jantung. Demikian juga dengan penelitian Thomas CT. Ho et al., (2011) membangun sebuah aplikasi desktop untuk membuktikan bahwa tempo musik berpengaruh terhadap denyut jantung. Aplikasi ini menggunakan alat $E C G$ seperti yang terdapat pada klinik kesehatan sehingga hasil pengukuran telah teruji. Ho menyimpulkan bahwa tempo musik dapat menaikan denyut jantung. Aplikasi ini memberikan gambaran baru sehingga dapat dikembangkan dalam aplikasi mobile.

Penelitian-penelitan yang telah dilakukan sebelumnya masih sangat sulit untuk diaplikasikan dalam kehidupan sehari-hari. Kesulitan terutama terjadi karena alat yang digunakan belum menunjang perangkat mobile. Di sisi lain penelitianyang menggunakan perangkat mobile masih terpaku pada pengukuran denyut jantung. Penelitian terdahulu tentang keterkaitan denyut jantung dan musik masih menitikberatkan pada relaksasi denyut jantung.

Dari pembahasan diatas dapat ditarik hipotesis bahwa tempo musik berpengaruh pada denyut jantung sehingga dapat digunakan sebagai media menaikan denyut jantung dan dapat digunakan sebagai penunjang aktivitas seseorang.

\section{Metodologi}

\subsection{Hardware dan Software}

Hardware yang digunakan dalam penelitian ini adalah smartphone dengan sistem operasi Android JellyBean yang mempunyai resolusi kamera 8 Megapixel. Notebook core i7 dengan system operasi windows 7. Software pendukung yang dibutuhkan adalah Android SDK 64bit, Eclipse Juno 64bit, Java Programing (JRE 7 dan JDK 7), Bpm Analyzer. BPM Analyzer digunakan sebagai dasar penentuan tempo musik sebelum di masukan ke dalam database pemutar musik. Keempat software tersebut merupakan freeware sehingga dapat dimodifikasi sesuai kebutuhan.

\subsection{Lingkungan dan Subyek Eksperimen}

Aplikasi diuji di lingkungan Fakultas Teknik Elektro Universitas Gadjahmada. Subyek diambil secara acak dari mahasiswa fakultas teknik. Ekperimen yang dilakukan meliputi dua eksperimen. Eksperimen pertama dilakukan untuk menguji aplikasi yang dikembangkan. Eksperimen yang kedua adalah ekperimen pendukung untuk mengetahui bahwa aplikasi dapat digunakan untuk menaikan denyut jantung. Eksperimen dilakukan setelah jam 3 sore dengan asumsi subyek dalam kondisi yang lelah. Hal ini diperlukan untuk membuktikan bahwa aplikasi ini dapat meningkatkan denyut jantung subyek. Batasan uji yang diambil adalah uji aplikasi dalam hal pengukuran jumlah denyut jantung dan persentase kenaikan denyut jantung yang terjadi adalah sebagai pendukung aplikasi.

Musik yang digunakan adalah acak. Tidak hanya melibatkan satu aliran musik tertentu. Akan tetapi untuk memperkecil database pada aplikasi diambil satu sampel lagu setiap kenaikan satu satuan tempo musik (bpm).

\subsection{Alur Kerja}

Terdapat tiga komponen utama yang berulang dalam aplikasi ini. Yang pertama adalah pengukuran denyut jantung yang dilakukan sensor kamera. Yang kedua adalah kalkulasi untuk mendapatkan tempo musik. Yang ketiga adalah eksekusi output berupa musik dengan tempo yang ditentukan proses kedua. proses tersebut berulang kembali pada pengambilan data denyut jantung yang kedua. Setelah denyut jantung yang kedua terukur maka proses selanjutnya adalah pemberian output musik dengan tempo lagu dan proses terus berulang. Secara keseluruhan alur kerja dapat digambarkan sebagai berikut:

1. Pengambilan data mentah denyut jantung. Dinotasikan sebagai $\boldsymbol{X}_{\boldsymbol{n}}$.

2. Kalkulasi denyut jantung untuk menentukan tempo musik $\left(\boldsymbol{Y}_{\boldsymbol{n}}\right)$ yang akan menjadi output. $\mathbf{Y}_{\mathbf{n}}=\mathbf{X}_{\mathbf{n}}+\mathbf{5 0 \%} \mathbf{X}_{\mathbf{n}}(\mathrm{bpm})$

3. Setelah $t$ menit maka data denyut jantung kedua akan diambil $\left(\mathbf{X}_{\mathbf{n}+\mathbf{1}}\right)$. Digunakan dsebagai data pembanding apakan denyut jantung sudah mengalami kenaikan atau belum.

4. Kalkulasi denyut jantung kedua untuk menentukan tempo musik.

$Y_{n+1}=X_{n+1}+50 \% X_{n+1}(b p m)$

5. Setelah $t$ menit maka proses kembali mengukur denyut jantung yang ketiga.

6. Proses berulang dari langkah pertama. 
Alur kerja di atas akan menghasilkan dokumen berupa tabel yang akan terisi secara otomatis pada setiap langkah kerja.

\subsection{Konsep Dasar}

Konsep yang digunakan adalah langkah berulang dari tiga komponen utama dalam sistem.

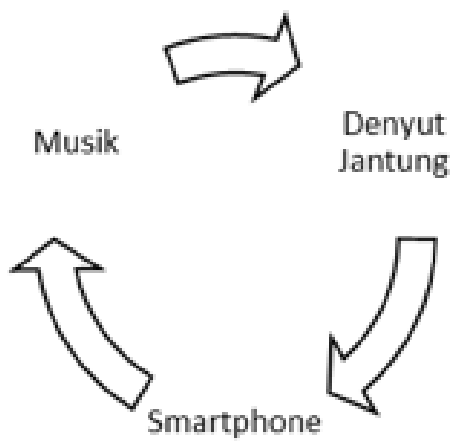

Gambar. 1. Konsep aplikasi

Tiga komponen utama yaitu denyut jantung, smartphone, dan musik. Denyut jantung yang diperoleh akan menjadi dasar smartphone melakukan kalkulasi untuk memberi output berupa tempo musik tertentu.

\subsection{Konsep Antar Muka Aplikasi}

Aplikasi ini dikembangkan menggunakan antarmuka yang sederhana. Dengan harapan dalam pengembangan perangkat ke depan dapat dengan mudah digunakan bahkan oleh orang yang tidak terlalu mengerti teknologi. Antar muka dapat dilihat pada Gambar 2.

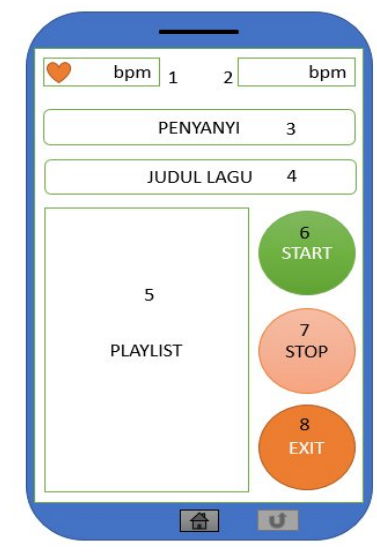

Gambar. 2. Antar muka aplikasi

Antarmuka terdiri dari 8 bagian yaitu:

1. Kolom kecil dengan simbol hati menunjukan pengukuran denyut jantung .

2. Kolom kecil sebagai petunjuk tempo musik yang diputar.
3. Kolom panjang nama penyanyi dari musik yang sedang diputar.

4. Kolom judul musik yang sedang diputar.

5. Kolom playlist lagu yang tersedia.

6. Tombol Hijau merupakan tombol Start, tombol untuk menjalankan aplikasi dengan langkah pertama mengukur denyut jantung.

7. Tombol berwarna Pink adalah tombol untuk berhenti menggunakan aplikasi.

8. Tombol Merah adalah tombol untuk menutup aplikasi menuju menu utama.

\subsection{Eksperimen}

Eksperimen terdiri dari 2 macam, yang pertama adalah eksperimen untuk menguji aplikasi dan yang kedua adalah eksperimen untuk mendukung fungsi dari aplikasi. Ekperimen pertama dilakukan dengan mencoba fungsi dari antar muka aplikasi dan fiturfitur yang ada.

Eksperimen kedua dimulai dengan memberikan waktu kepada subyek sehingga dalam keadaan rileks. Subyek diambil dengan kondisi dan lingkungan yang acak. Dalam keadaan rileks subyek mengenakan headphone yang terhubung pada smartphone sebagai alat dengar. Langkah selanjutnya adalah pengukuran denyut jantung dengan meletakan kamera smartphone pada ujung jari untuk pengambilan data denyut jantung.

Setelah tombol start ditekan maka aplikasi akan mengukur denyut jantung selama 20 detik. setelah aplikasi selesai mengukur denyut jantung proses berikutnya adalah mendengar musik dengan tempo tertentu. Setelah musik selesai diputar maka aplikasi akan memberikan peringatan untuk pengukuran denyut jantung yang kedua. Proses akan berulang sehingga didapat tiga kali pengukuran denyut jantung.

\section{Hasil dan Pembahasan}

\subsection{Uji Aplikasi}

Hasil uji eksperimen pertama terhadap prototype aplikasi ini menunjukan bahwa aplikasi dapat berjalan dengan baik. Fitur-fitur yang terdapat dalam aplikasi dapat dijalankan dengan baik. Kolom denyut jantung sudah dapat menampilkan denyut jantung yang terukur. Kolom tempo musik sudah menunjukkan tempo yang sesuai dengan tempo musiknya. Kolom penyanyi, judul lagu dan playlist sudah menunjukan fungsinya dengan baik. Tombol Start, Stop dan Exit juga telah berfungsi dengan baik.

Hasil uji aplikasi menunjukan aplikasi telah siap untuk diujikan pada subyek.

\subsection{Uji Subyek}

Pengujian awal aplikasi pada subjek menunjukan hasil yang baik. Ditunjukkan dengan meningkatnya denyut jantung setelah pemberian output tempo tertentu pada subjek. 
Tabel. 1. Uji awal

\begin{tabular}{ccccccc}
\hline No & $\mathrm{L} / \mathrm{P}$ & $\mathrm{Xn}$ & $\mathrm{Yn}$ & $\mathrm{Xn}_{+1}$ & $\mathrm{Yn}_{+1}$ & $\mathrm{Xn}_{+2}$ \\
\hline 1 & $\mathrm{~L}$ & 80 & 120 & 85 & 128 & 86 \\
2 & $\mathrm{~L}$ & 47 & 80 & 81 & 122 & 83 \\
\hline
\end{tabular}

Pada awal uji aplikasi terdapat pengukuran denyut jantung dibawah standar. Dimana denyut jantung orang normal berkisar 60 bpm - 100 bpm.

Ketidaknormalan ini dapat disebabkan dari beberapa faktor. Faktor yang paling mendasar adalah ketidakstabilan sensor kamera dalam mengukur denyut jantung. Hal ini dimungkinkan karena penurunan kualitas sampel gambar yang diambil atau dapat juga cahaya lampu flash yang terpancar tidak konstan sehingga menimbulkan noise pada sampel gambar.

Faktor lain adalah kondisi jantung subyek, dimana dalam fase relaksasi jantung antar individu mempunyai karakteristik yang berlainan. Misalnya seorang olahragawan dan bukan olahragawan akan berbeda tipikal denyut jantungnya dalam fase relaksasi ataupun dalam fase optimum.

Tahap awal aplikasi telah menunjukan hal yang positif. Pengembangan aplikasi agar hasil ukur denyut jantung lebih valid sedang dalam proses pengerjaan.

\section{Kesimpulan}

Tujuan utama pengukuran denyut jantung secara mobile telah terpenuhi. Meskipun belum terlalu signifikan kenaikan denyut jantung karena tempo musik sudah terlihat dari hasil uji subyek. Hal tersebut menunjukan bahwa aplikasi dapat digunakan untuk mengukur dan meningkatkan denyut jantung sebagai penunjang rutinitas. Karena suplai oksigen pada otak akan bertambah seiring dengan kenaikan denyut jantung.

Selama pengembangan aplikasi terdapat beberapa hal yang dapat diamati untuk meningkatkan fungsi dan efektifitas dari aplikasi. Misalnya penggunaan satu aliran musik tertentu dapat meningkatkan denyut jantung dengan lebih signifikan. Atau dengan output tempo yang lebih rendah, aplikasi dapat digunakan sebagai media relaksasi. Keakuratan pengukuran juga menjadi prioritas dalam pengembangan aplikasi ke depan. Penambahan uji subyek perlu dilakukan untuk mengetahui efektifitas aplikasi.

\section{Daftar Pustaka}

Al-Taee, M.A., Jaradat, N.A., Ali, D.M.A., 2011. Mobile phone-based health data acquisition system using Bluetooth technology. Presented at the Applied Electrical Engineering and Computing Technologies (AEECT), 2011 IEEE Jordan Conference on, pp. 1-6. doi:10.1109/AEECT.2011.6132524
De Castro, B.C.., Guida, H.L.., Roque, A.L.., De Abreu, L.C.., Ferreira, L.L.., Raimundo, R.D.., Monteiro, C.B.., Goulart, F.C.., Ferreira, C.., Marcomini, R.S.., Ribeiro, V.F.., Ré, A.H.., Vanderlei, L.C.M.., Valenti, V.E.., 2013. Previous exposure to musical auditory stimulation immediately influences the cardiac autonomic responses to the postural change maneuver in women. Int. Arch. Med. 6. doi:10.1186/17557682-6-32

Diab, M.O., Marak, R.A., Dichari, M., Moslem, B., 2013. The smartphone accessory heart rate monitor. Presented at the Computer Medical Applications (ICCMA), 2013 International Conference on, pp. 1-5. doi:10.1109/ICCMA.2013.6506185

Dousty, M., Daneshvar, S., 2010. The effect of different kind of music and silences on electrical heart working. Isfahan. doi:10.1109/ICBME.2010.5704936

Fraile, J.A., Bajo, J., Corchado, J.M., Abraham, A., 2010. Applying Wearable Solutions in Dependent Environments. Inf. Technol. Biomed. IEEE Trans. On 14, 1459-1467. doi:10.1109/TITB.2010.2053849

Gregoski, M.J., Mueller, M., Vertegel, A., Shaporev, A., Jackson, B.B., Frenzel, R.M., Sprehn, S.M., Treiber, F.A., 2012. Development and validation of a smartphone heart rate acquisition application for health promotion and wellness telehealth applications. Int. J. Telemed. Appl. 2012, 1.

Hii, P., Chung, W., 2011. A comprehensive ubiquitous healthcare solution on an Android ${ }^{\mathrm{TM}}$ mobile device. Sensors 11, 6799-6815.

Ho, C.-L.. b, Fu, Y.-C.. c, Lin, M.-C.. c, Chan, S.-C.., Hwang, B.., Jan, S.-L.. c, 2013. Smartphone Applications (Apps) for Heart Rate Measurement in Children: Comparison with Electrocardiography Monitor. Pediatr. Cardiol. 16. doi: 10.1007/s00246-013-0844-8

Ho, T.C.T., Xiang Chen, 2011. iHeartLift: A closed loop system with bio-feedback that uses music tempo variability to improve heart rate variability. Presented at the Engineering in Medicine and Biology Society,EMBC, 2011 Annual International Conference of the IEEE, pp. 11811184. doi:10.1109/IEMBS.2011.6090277

Issac, R., Ajaynath, M.S., 2012. CUEDETA:A real time heart monitoring system using android smartphone. Presented at the India Conference (INDICON), 2012 Annual IEEE, pp. 047-052. doi:10.1109/INDCON.2012.6420587

Lakens, D., 2013. Using a Smartphone to Measure Heart Rate Changes during Relived Happiness and Anger. Affect. Comput. IEEE Trans. On 4, 238-241. doi:10.1109/T-AFFC.2013.3

McCraty, R., Mike Atkinson, Dana Tomasino, 2001. Science of the Heart: Exploring the Role of the 
Heart in Human Performance. Inst. Hear. Res. Staff 1.

Nasri, F., Moussa, N., Mtibaa, A., 2013. Smart mobile system for health parameters follow ship based on WSN and android. Presented at the Computer and Information Technology (WCCIT), 2013 World Congress on, pp. 1-6. doi:10.1109/WCCIT.2013.6618733

Raglio, A.. b c, Oasi, O.., Gianotti, M.., Bellandi, D.., Manzoni, V.., Goulene, K.., Imbriani, C.., Badiale, M.S.., 2012. Music therapy, emotions and the heart: A pilot study. G. Ital. Med. Lav. Ergon. 34, 438-443.

Santoso, D.S., 2002. Pengaruh musik terhadap performance fisik. Jurnal Teknik Industri Vol. 4, $1-7$.

Singh, K., Crilly, P., Muthukkumarasamy, V., 2012. Sensing and analyzing physiological data with a smart phone to secure an e-health system. Presented at the Communications and Information Technologies (ISCIT), 2012 International Symposium on, pp. 302-307. doi:10.1109/ISCIT.2012.6380911.
Sung-Yuan Ko, Kang-Min Wang, Wei-Cheng Lian, Chun-Heng Kao, 2012. A portable ECG recorder. Presented at the Consumer Electronics, Communications and Networks (CECNet), 2012 2nd International Conference on, pp. 3063-3067. doi:10.1109/CECNet.2012.6201460

Watanabe, H., Kawarasaki, M., Sato, A., Yoshida, K., 2012. Development of wearable heart disease monitoring and alerting system associated with smartphone. Presented at the e-Health Networking, Applications and Services (Healthcom), 2012 IEEE 14th International Conference on, pp. 292-297. doi:10.1109/HealthCom.2012.6379423

Weibo Song, Hong Yu, Ce Liang, Qihua Wang, Yunfeng Shi, 2012. Body monitoring system design based on android smartphone. Presented at the Information and Communication Technologies (WICT), 2012 World Congress on, pp. $1147-1151$. doi:10.1109/WICT.2012.6409247

Zeydi, A.E.., Jafari, H.., Khani, S.., Esmaeili, R.., Baradari, A.G.., 2011. The effect of music on the vital signs and $\mathrm{SpO} 2$; of patients after open heart surgery: A randomized clinical trial. J. Mazandaran Univ. Med. Sci. 20, 72-82. 